THE mechanisms responsible for development of inflammatory bowel disease (IBD) have not been fully elucidated, although the main cause of disease pathology is attributed to up-regulated inflammatory processes. The aim of this study was to investigate frequencies of polymorphisms in genes encoding pro-inflammatory and anti-inflammatory markers in IBD patients and controls. We determined genotypes of patients with IBD $(n=172)$ and healthy controls $(n=389)$ for polymorphisms in genes encoding

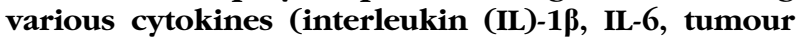
necrosis factor (TNF), IL-10, IL-1 receptor antagonist). Association of these genotypes to disease incidence and pathophysiology was investigated. No strong association was found with occurrence of IBD. Variation was observed between the ulcerative colitis study group and the control population for the TNF- $\alpha-308$ polymorphism $(p=0.0135)$. There was also variation in the frequency of IL-6-174 and TNF- $\alpha-308$ genotypes in the ulcerative colitis group compared with the Crohn's disease group $(p=0.01)$. We concluded that polymorphisms in inflammatory genes are associated with variations in IBD phenotype and disease susceptibility. Whether the polymorphisms are directly involved in regulating cytokine production, and consequently pathophysiology of IBD, or serve merely as markers in linkage disequilibrium with susceptibility genes remains unclear.

Key words: Inflammatory bowel disease, Cytokine, Polymorphism

\section{Inflammatory bowel disease: the role of inflammatory cytokine gene polymorphisms}

\author{
Joanna Balding ${ }^{1}$, Wendy J. Livingstone', \\ Judith Conroy², Lesley Mynett-Johnson ${ }^{2}$, Donald G. \\ Weir $^{3}$, Nasir Mahmud ${ }^{3}$ and Owen P. Smith ${ }^{4, C A}$
}

${ }^{1}$ Thrombosis and Haemostasis Laboratory, Institute of Molecular Medicine, and ${ }^{3}$ Department of Clinical Medicine, Trinity Centre for Health Sciences, St James's Hospital, Dublin 8, Ireland; ${ }^{2}$ Department of Genetics, Trinity College, Dublin 2, Ireland;

${ }^{4}$ Department of Haematology, Our Lady's Hospital for Sick Children, Crumlin, Dublin 12, Ireland

\footnotetext{
${ }^{\mathrm{CA}}$ Corresponding author

Tel: + $35314096055 / 6056$

E-mail: owen.smith@olhsc.ie
}

\section{Introduction}

Inflammatory bowel disease (IBD), a significant health problem in the developed world, comprises two chronic relapsing and remitting inflammatory disorders of the gastrointestinal tract: ulcerative colitis (UC) and Crohn's disease (CD). ${ }^{1} \mathrm{UC}$, which has a slightly higher incidence than $\mathrm{CD}$, affects only the large bowel, whereas CD can affect any part of the gastrointestinal tract. The general symptoms of UC are malaise, lethargy, and anorexia accompanied by diarrhoea with blood and mucus, abdominal discomfort, and fever. ${ }^{1}$ The symptoms of CD tend to be more varied, depending on its site in the digestive tract, and can occur in a mild, moderate or severe form characterised by cycles of remission and active disease. These can include some or all of the symptoms of UC, although extra-intestinal manifestations are also common in CD such as inflammation of the eye, skin, joints, and mouth; arterial and venous thrombosis; chronic hepatitis; and other complications involving the liver, biliary tract, and kidneys. ${ }^{1-3}$

Little is known about the underlying immunopathogenesis of IBD. However, both UC and CD are characterised by activation of macrophages and $\mathrm{T}$ lymphocytes; pro-inflammatory cytokine, chemokine, and adhesion molecule expression; and an inability to adequately down-regulate immune activation. IBD, particularly $\mathrm{CD}$, is characterised by a predominantly $\mathrm{T}$ helper (Th) 1 type profile, involving the up-regulation of cytokines such as interleukin (IL)-6, IL-8, IL-1 $\beta$, and tumour necrosis factor (TNF)$\alpha^{4-6}$ TNF antibody therapy has been found to improve both $\mathrm{CD}$ and $\mathrm{UC}$, indicating a pivotal role for this cytokine in these conditions. ${ }^{7-9}$ Blocking IL-1 action with the IL-1 receptor antagonist (IL-1Ra) in animals with immune-complex-mediated colitis reduces the severity of inflammation and lowers eicosanoid concentrations in the bowel. ${ }^{10,11}$ Reduced levels of IL-10, an anti-inflammatory Th2 cytokine, are also potentially important in the pathogenesis of IBD, and encouraging results have been obtained with IL-10 therapy in IBD when administered topically in UC and systemically in active CD patients. ${ }^{12,13}$

A genetic background resulting in up-regulated inflammation leading to IBD has been suggested by a number of studies, including that of Tysk et al. who estimated the heritability of CD (1.0, 95\% confidence interval, $0.34-1.0)$ and UC (0.53, 95\% confidence interval, $0.24-1.0)$ using the concordance rate in twin 
pairs. ${ }^{14}$ Using 'age specific incidence data' to calculate the age-corrected empiric risk estimates, the risk of developing IBD has been determined to be $8.9 \%$ for offspring if either parent suffers IBD, 8.8\% for siblings of a patient, and 3.5\% for parents of an afflicted child. ${ }^{15}$

We postulated that small differences in cytokine levels as a result of gene polymorphisms may have an important effect on the inflammatory response and thus influence the pathophysiology of IBD. Here, we investigate frequencies of a range of polymorphisms in genes encoding pro-inflammatory cytokines (IL$1 \beta$, IL- 6 , TNF- $\alpha$, and TNF- $\beta$ ) and anti-inflammatory markers (IL-10, IL-1Ra) in a group of individuals with IBD and a large control population. We also aimed to compare genotype frequencies in UC and CD patients, in order to highlight possible differences between these two IBD disease groups. A number of the polymorphisms studied have been previously reported to have functional effects on the levels of the protein that they encode and have also been associated with various inflammatory and/or autoimmune diseases (Table 1).

\section{Materials and methods}

\section{Patients and controls}

Ethylenediamine tetraacetic acid anti-coagulated whole blood was collected from 389 healthy blood donors (female, 42\%; male, 58\%; mean age, 37.1 years; age range, 18-65 years) and 172 patients with established IBD recruited from St James's Hospital, Dublin (female, 59\%; male, 41\%; mean age of disease onset, 30.8 years; median age of disease onset, 29.5 years; range of disease onset, 4-69 years). The disease group consisted of 64 patients with CD (female, 72\%; male, 28\%; mean age of disease onset, 30 years; median age of disease onset, 29 years; range of disease onset, 4-69 years) and 108 patients with UC (female, 52\%; males, 48\%; mean age of disease onset, 31.5 years; median age of disease onset, 30 years; range of disease onset, $12-61$ years). Donor bloods for use as control samples were collected from The Northern Ireland Blood Transfusion Service ( $n=60)$ and The Blood Transfusion Service Board (Dublin and Cork and mobile units throughout the Republic of Ireland) $(n=329)$. The study was approved by the St James's Hospital ethics committee and consent obtained from all participating subjects.

\section{DNA isolation}

DNA was extracted from whole blood using overnight proteinase $\mathrm{K}(1 \mathrm{mg} / \mathrm{ml})$ cell lysis at $37^{\circ} \mathrm{C}$ in the presence of $0.5 \%$ sodium dodecyl sulphate followed by phenol/chloroform extraction and ethanol precipitation.

Table 1. Cytokine gene polymorphisms: effects on gene expression and disease associations

\begin{tabular}{|c|c|c|c|}
\hline Gene & Polymorphism & Functional effect & Disease association* \\
\hline IL-6 & $-174 \mathrm{G} \rightarrow \mathrm{C}^{16}$ & $\begin{array}{l}\text { G: } \uparrow \text { IL- } 6 \text { in normal individuals and in reporter } \\
\text { gene assays (LPS/IL- } 1 \text { stimulation) }{ }^{16} \\
\text { No association with IL- } 6 \text { levels in CAD patients }{ }^{17} \\
\text { or in sepsis patients }\end{array}$ & S-JCA,${ }^{16} \mathrm{CAD}^{19}$ \\
\hline TNF- $\beta$ & $\begin{array}{l}+252 \mathrm{~A} \rightarrow \mathrm{G} \\
(\mathrm{B} 2 \rightarrow \mathrm{B} 1)(\mathrm{TNFB})^{20}\end{array}$ & $\begin{array}{l}\text { B2: } \uparrow \text { TNF- } \alpha \text { expression in stimulated PBMC, } \\
\text { in severe sepsis patients } \\
\text { No effect on TNF- } \alpha^{20,23} \\
\text { B1: } \uparrow \text { TNF- } \beta \text { in stimulated PBMC } \\
\text { B2: } \uparrow \text { TNF- } \beta \text { in stimulated PBMC } \\
\text { No effect on TNF- } \beta \text { in stimulated PBMC }\end{array}$ & Outcome in severe sepsis ${ }^{22,24}$ \\
\hline TNF- $\alpha$ & $-308 \mathrm{G} \rightarrow \mathrm{A}$ & $\begin{array}{l}\text { A: } \uparrow \text { TNF- } \alpha \text { expression in vitro }{ }^{25} \text { and in vivo }{ }^{26} \\
\text { No effect on TNF- } \alpha \text { response to LPS } 27\end{array}$ & $\begin{array}{l}\text { Outcome in meningococcal } \\
\text { disease, }{ }^{28} \text { septic shock }\end{array}$ \\
\hline IL-10 & $-592 C \rightarrow A^{30}$ & $\begin{array}{l}\text { Generally no association } \\
\text { A: } \downarrow \text { IL-10 expression in critically ill patients }\end{array}$ & Mortality in critically ill patients ${ }^{31}$ \\
\hline IL-10 & $-1082 \mathrm{G} \rightarrow \mathrm{A}^{30}$ & $\begin{array}{l}\text { G: } \uparrow \text { IL-10 expression in stimulated lymphocytes, } \\
\text { in control and CD patients } \\
\text { No effect on IL-10 levels }\end{array}$ & $\mathrm{IBD}^{33}$ \\
\hline IL-1RN & Intron 2, 86 bp VNTR ${ }^{34}$ & $\begin{array}{l}\text { A2: } \uparrow \text { IL-1Ra and } \downarrow \text { IL- } 1 \alpha \text { expression in } \\
\text { GM-CSF-stimulated monocytes }{ }^{35} \\
\text { A2: } \downarrow \text { IL-1Ra in cultured PBMC }{ }^{36} \\
\text { A2: } \uparrow \text { IL-1 } \beta \text { in cultured PBMC } \text { PB }^{37}\end{array}$ & $\mathrm{IBD}^{38}$ \\
\hline IL-1 $\beta$ & $+3953 \mathrm{C} \rightarrow \mathrm{T}^{39}$ & $\begin{array}{l}\mathrm{T}: \uparrow \mathrm{IL}-1 \beta \text { expression in LPS-stimulated monocytes } \\
\text { No effect on in vivo IL- } 1 \beta \text { levels } \\
\text { No,41 }\end{array}$ & $\mathrm{IBD}^{42}$ \\
\hline
\end{tabular}

$\uparrow$ or $\downarrow$, increase or decrease in expression compared with other alleles of the same polymorphism; $\rightarrow$, single base substitution; PBMC, peripheral blood mononuclear cells; CAD, coronary artery disease; S-JCA, systemic-onset juvenile chronic arthritis; VNTR, variable number of tandem repeats; LPS, lipopolysaccharide.

* Not all published disease associations are included in the table. 
Polymerase chain reaction, restriction enzyme digestion, and agarose gel electrophoresis

Polymerase chain reaction (PCR) amplification of all polymorphic sites was performed in a $50 \mu$ l total volume. The standard reaction mix consisted of Taq DNA Polymerase buffer with $\mathrm{MgCl}_{2}$ (Promega, Madison, WI, USA) (50 mM KCl, $10 \mathrm{mM}$ Tris- $\mathrm{HCl}$ ( $\mathrm{pH}$ 9.0), $0.1 \%$ Triton X-100, and $1.5 \mathrm{mM} \mathrm{MgCl}_{2}$ ), $0.4 \mathrm{U}$ of DNA Taq polymerase, $2 \mu$ of genomic DNA, 4\% dimethyl sulphoxide, $30 \mu \mathrm{M}$ each of deoxyribonucleoside triphosphates, and $0.2 \mu \mathrm{M}$ each of sense primer and antisense primer (Table 2). The cycling parameters for each assay are presented in Table 3, along with any changes to the standard PCR reaction mix. Restriction enzymes (New England BioLabs, Beverly, MA, USA; except Hsp 92 II, from Promega) used for each assay are presented in Table 2. The IL-6, TNF- $\alpha$, IL-10-1082, and IL-10-592 PCR products were digested with the appropriate enzyme overnight at $37^{\circ} \mathrm{C}$. The TNFB PCR product was digested for $3 \mathrm{~h}$ at $37^{\circ} \mathrm{C}$, and the IL-1 $\beta$ PCR product was digested for 12 $\mathrm{h}$ at $65^{\circ} \mathrm{C}$. Restriction digest products were run in the appropriate percentage of agarose gel (Table 3) containing $1.6 \mu \mathrm{g} / \mathrm{ml}$ of ethidium bromide.

\section{Statistical analysis}

Allele and genotype frequencies were compared between patient and control groups, and between patient subpopulations, by means of the chi-squared test and Fischer's exact test when appropriate. A chisquared $p<0.05$ was considered statistically significant. Allele frequencies were determined by gene counting. Odds ratios and corresponding 95\% confidence intervals were estimated by cross-tabulation. Statistics were performed using Statview software
(Statview version 4.5; Abacus Concepts Inc., Berkeley, CA, USA).

\section{Results}

\section{IBD and controls}

Genotype and allele frequencies for all seven polymorphisms in the control group, IBD group, UC group, and CD group are presented in Table 4. No association was found between any of the seven polymorphisms in this study and the occurrence of IBD, excepting the IL-1 $\beta$ polymorphism where the CC genotype was at a higher frequency in the disease population compared with the control population (72\% versus $61 \%, p=0.046)$.

\section{UC, CD and controls}

The IBD study group can be divided into two groups: patients suffering from UC and those suffering from CD. A significant difference was observed when comparing the UC study group with the control population for the TNF- $\alpha-308$ polymorphism, with carriers of the $-308 \mathrm{~A}$ allele at a lower frequency in the UC group (28\%) compared with the control group $(40 \%)(p=0.02)$. There was no association between any of the other polymorphisms studied and the occurrence of either form of IBD when comparing with the control group, although the IL-1RN (gene encoding the IL-1Ra protein) A2A2 genotype was almost twice the frequency in the CD group (14\%) than that observed in either the control population $(8 \%)$ or the UC population $(7 \%)(p=0.088)$. Our study found a significant difference in the frequency of IL-6-174 genotypes in the UC group ( $G G=40 \%$, $\mathrm{GC}=41 \%, \mathrm{CC}=19 \%)$ compared with the CD group

Table 2. PCR primer sequences with the position of the $5^{\prime}$ base, restriction enzymes, and cut sites

\begin{tabular}{|c|c|c|c|c|c|}
\hline \multirow[t]{2}{*}{ Primer } & \multirow[t]{2}{*}{ Sequence $\left(5^{\prime}-3^{\prime}\right)$} & \multirow{2}{*}{$\begin{array}{l}\text { Position of } \\
5^{\prime} \text { base }\end{array}$} & \multirow{2}{*}{$\begin{array}{l}\text { Restriction } \\
\text { enzyme }\end{array}$} & \multicolumn{2}{|c|}{ Restriction sites } \\
\hline & & & & Variant & Constant \\
\hline $\begin{array}{l}\text { IL-6-174 sense } \\
\text { - } 174 \text { - }\end{array}$ & $\begin{array}{l}\text { ATGACTTCAGCTTTACTCTT } \\
\text { ATAAATT }\end{array}$ & $\begin{array}{r}-324 \\
-81\end{array}$ & Hsp 92 II & -174 & -296 \\
\hline TNFB sense* & CCCTCCTGCACCTGCTGCCTGG & $\begin{array}{r}-81 \\
+112\end{array}$ & Hinf I & +251 & +196 \\
\hline TNFB antisense ${ }^{*}$ & AGAGGGG TGGATGCTTGGGTTC & +833 & & & \\
\hline TNF- $\alpha-308$ sense & GGAGGCAATAGGTTTTGAGGGCCAT & -334 & Nco I & -313 & -162 \\
\hline TNF- $\alpha-308$ antisense & CTGTCTCGGT TTCTTCTCCATGGCG & -140 & & & \\
\hline IL-10-1082 sense & TCTGAAGAAGTCCTGATGTC & -1248 & Mnl I & -1085 & $-1196,-1191$ \\
\hline IL-10-1082 antisense & СТСТTАССТАТСССТАСТTСС & -1059 & & -1081 & -1174 \\
\hline IL-10-592 sense & GACTCCAGCCACAGAAGCTTA & -967 & Rsa I & -594 & $-884,-842$ \\
\hline IL-10-592 antisense & ATATCCTCAAAGTTCCCAAGC & -531 & & & -834 \\
\hline IL- $1 \beta+3953$ sense & GTGTTGTCATCAGACTTTGACCGTA & +3816 & Taq I & +3952 & +4052 \\
\hline IL-1 $\beta+3953$ antisense & GAGAGCTTTCAGTTCATATCGACCA & +4073 & & & \\
\hline IL-1RN sense** & CTCAGCAACACTCCTAT & Intron 2 & N/A & $\mathrm{N} / \mathrm{A}$ & N/A \\
\hline IL-1RN antisense & GCAGCAATAATGAAGAG & Intron 2 & & & \\
\hline
\end{tabular}

* TNFB primers from Stüber et al. ${ }^{22}$

** IL-1RN sense primer from Fang et al. ${ }^{24}$ 
Table 3. PCR cycling parameters, changes to standard reaction mix, and percentage agarose gel used in each assay

\begin{tabular}{lcllllc}
\hline Polymorphism & $\begin{array}{c}\text { Cycles } \\
(n)\end{array}$ & Denaturation & Annealing & Elongation & $\begin{array}{c}\text { Changes to standard } \\
\text { reaction mix }\end{array}$ & $\begin{array}{c}\text { Agarose } \\
\text { gel (\%) }\end{array}$ \\
\hline IL-6-174 & 40 & $94^{\circ} \mathrm{C}, 1 \mathrm{~min}$ & $58^{\circ} \mathrm{C}, 1 \mathrm{~min}$ & $72^{\circ} \mathrm{C}, 90 \mathrm{sec}$ & & 3 \\
TNFB* & 37 & $95^{\circ} \mathrm{C}, 30 \mathrm{sec}$ & $68^{\circ} \mathrm{C}, 30 \mathrm{sec}$ & $74^{\circ} \mathrm{C}, 42 \mathrm{sec}$ & $1 \mu \mathrm{M}$ each primer & 2 \\
TNF- $\alpha-308$ & 40 & $94^{\circ} \mathrm{C}, 1 \mathrm{~min}$ & $65^{\circ} \mathrm{C}, 1 \mathrm{~min}$ & $72^{\circ} \mathrm{C}, 1 \mathrm{~min}$ & & 2 \\
IL-10-1082 & 40 & $94^{\circ} \mathrm{C}, 1 \mathrm{~min}$ & $58^{\circ} \mathrm{C}, 1 \mathrm{~min}$ & $72^{\circ} \mathrm{C}_{1} 1 \mathrm{~min}$ & No DMSO & 4 \\
IL-10-592 & 40 & $94^{\circ} \mathrm{C}, 1 \mathrm{~min}$ & $64^{\circ} \mathrm{C}, 1 \mathrm{~min}$ & $72^{\circ} \mathrm{C}_{1} 1 \mathrm{~min}$ & $1 \mu \mathrm{M}$ each primer & 3 \\
IL-1 $\beta+3953$ & 40 & $94^{\circ} \mathrm{C}, 1 \mathrm{~min}$ & $65^{\circ} \mathrm{C}, 1 \mathrm{~min}$ & $72^{\circ} \mathrm{C}, 1 \mathrm{~min}$ & & 3 \\
IL-1RN 86 bp VNTR & 40 & $94^{\circ} \mathrm{C}, 1 \mathrm{~min}$ & $58^{\circ} \mathrm{C}, 1 \mathrm{~min}$ & $72^{\circ} \mathrm{C}, 90 \mathrm{sec}$ & $1 \mu \mathrm{M}$ each primer; $6 \%$ DMSO & 2
\end{tabular}

DMSO, dimethyl sulphoxide; VNTR, variable number of tandem repeats.

* TNFB cycling parameters from Stüber et al. ${ }^{22}$

$(\mathrm{GG}=22 \%, \quad \mathrm{GC}=64 \%, \quad \mathrm{CC}=14 \%) \quad(p=0.011) . \quad \mathrm{A}$ similar association was seen for the TNF- $\alpha-308$ polymorphism (UC group, GG $=72 \%, G A=21 \%$, $\mathrm{AA}=7 \% ; \mathrm{CD}$ group, $\mathrm{GG}=53 \%, \mathrm{GA}=41 \%, \mathrm{AA}=$ $1 \% ; p=0.0135)$.

\section{Age of IBD onset}

No association was seen between age of disease onset and any of the seven polymorphisms studied, either for the IBD group as a whole or when dividing into UC and CD groups.

\section{Discussion}

The pathophysiological mechanisms responsible for the development of IBD have not yet been fully determined. The main cause of disease pathology is, as the name suggests, up-regulated inflammatory processes, the consequence of which is inflammatory cell infiltration in lamina propria, and crypt abscesses; goblet cell depletion in the case of UC; and inflammation in all bowel layers in CD, with lymphoid hyperplasia and an increased presence of chronic inflammatory cells. ${ }^{1}$ Although infectious or other external agents are probable contributors to IBD pathogenesis, or might trigger disease onset, and the immune system clearly mediates tissue damage in the disease, it appears from available data that genetic factors play a role in determining the susceptibility of a given individual to IBD. ${ }^{15}$ Since IBD is characterised by a failure to confine the usual self-limited gut inflammatory response, genes involved in determining the level of the immune response in the inflammatory pathway might be risk factors in the disease. We therefore examined the potential association of a group of polymorphisms in cytokine

Table 4. Genotype counts (\%) and allele frequencies of seven polymorphisms in a control population and an IBD patient population, and in subdivisions of the IBD population (UC and CD groups)

\begin{tabular}{|c|c|c|c|c|c|c|c|c|c|c|}
\hline \multirow[t]{2}{*}{ Polymorphism } & \multicolumn{5}{|c|}{ Genotype count (\%) } & \multicolumn{5}{|c|}{ Allele frequency } \\
\hline & Genotype & Control $(n=389)$ & $\operatorname{IBD}(n=172)$ & UC $(n=108)$ & $\mathrm{CD}(n=64)$ & Allele & Control & IBD & UC & $C D$ \\
\hline \multirow[t]{3}{*}{ IL-6-174 } & GG & $123(32)$ & 57 (33) & $43(40)$ & $14(22)$ & G & 0.57 & 0.58 & 0.61 & 0.54 \\
\hline & $\mathrm{GC}$ & 198 (51) & 85 (49) & $44(41)$ & $41(64)$ & C & 0.43 & 0.42 & 0.39 & 0.46 \\
\hline & CC & 68 (17) & 30 (18) & 21 (19) & $9(14)$ & & & & & \\
\hline \multirow[t]{3}{*}{ TNFB } & B1B1 & $52(13)$ & $25(15)$ & $18(17)$ & $7(11)$ & B1 & 0.40 & 0.39 & 0.38 & 0.41 \\
\hline & B1B2 & 205 (53) & $86(50)$ & 47 (43) & $39(61)$ & B2 & 0.60 & 0.61 & 0.62 & 0.59 \\
\hline & B2B2 & $132(34)$ & 61 (35) & $43(40)$ & $18(28)$ & & & & & \\
\hline \multirow[t]{3}{*}{ TNF- $\alpha-308$} & GG & $233(60)$ & 115 (67) & 78 (72) & 37 (58) & G & 0.78 & 0.81 & 0.83 & 0.78 \\
\hline & $\mathrm{GA}$ & $140(36)$ & $49(28)$ & $23(21)$ & $26(41)$ & A & 0.22 & 0.19 & 0.17 & 0.22 \\
\hline & AA & $16(4)$ & $8(5)$ & 7 (7) & $1(1)$ & & & & & \\
\hline \multirow[t]{3}{*}{ IL-10-1082 } & GG & $123(32)$ & $61(36)$ & 37 (34) & $24(38)$ & G & 0.55 & 0.58 & 0.56 & 0.60 \\
\hline & $\mathrm{GA}$ & $180(46)$ & 77 (44) & $48(45)$ & $29(45)$ & A & 0.45 & 0.42 & 0.44 & 0.40 \\
\hline & $A A$ & $86(22)$ & $34(20)$ & $23(21)$ & 11 (17) & & & & & \\
\hline \multirow[t]{3}{*}{ IL-10-592 } & $\mathrm{CC}$ & $235(60)$ & $116(68)$ & $72(67)$ & $44(69)$ & C & 0.78 & 0.82 & 0.81 & 0.84 \\
\hline & CA & 139 (36) & 50 (29) & $31(29)$ & $19(30)$ & A & 0.22 & 0.18 & 0.19 & 0.16 \\
\hline & AA & $15(4)$ & $6(3)$ & $5(4)$ & $1(1)$ & & & & & \\
\hline \multirow{3}{*}{ IL-1 $\beta+3953$} & $\mathrm{CC}$ & $240(62)$ & $124(72)$ & 78 (72) & $46(72)$ & C & 0.78 & 0.83 & 0.83 & 0.83 \\
\hline & $\mathrm{CT}$ & 125 (32) & $38(22)$ & $24(22)$ & $14(22)$ & $\mathrm{T}$ & 0.22 & 0.17 & 0.17 & 0.17 \\
\hline & TT & $24(6)$ & $10(6)$ & $6(6)$ & $4(6)$ & & & & & \\
\hline \multirow{7}{*}{ IL-1RN VNTR } & $\mathrm{A} 1 \mathrm{~A} 1$ & 183 (47) & 73 (43) & $48(44)$ & 25 (39) & $\mathrm{A} 1$ & 0.69 & 0.66 & 0.685 & 0.617 \\
\hline & A1A2 & 159 (41) & $70(41)$ & $44(41)$ & $26(41)$ & A2 & 0.29 & 0.30 & 0.278 & 0.359 \\
\hline & A1A4 & $0(0)$ & $1(0.5)$ & $1(1)$ & $0(0)$ & A3 & 0.02 & 0.03 & 0.028 & 0.024 \\
\hline & $\mathrm{A} 2 \mathrm{~A} 2$ & $31(8)$ & $18(10)$ & $8(7)$ & $10(15)$ & A4 & 0.00 & 0.003 & 0.005 & \\
\hline & A1A3 & $15(4)$ & 9 (5) & $6(6)$ & $3(5)$ & A5 & 0.00 & 0.003 & 0.005 & \\
\hline & A1A5 & $0(0)$ & $1(0.5)$ & 1 (1) & $0(0)$ & & & & & \\
\hline & A2A3 & $1(0.2)$ & $0(0)$ & $0(0)$ & $0(0)$ & & & & & \\
\hline
\end{tabular}

VNTR, variable number of tandem repeats. 
genes with the occurrence of IBD and of UC and CD patient subsets.

When comparing the complete IBD population with controls, a significant variation in genotype frequency of the IL-1 $\beta$ promoter polymorphism was found. Higher levels of the pro-inflammatory cytokine IL- $1 \beta$ would be expected to increase the likelihood of developing IBD, since higher levels of such cytokines occur in this disease. This study detected higher levels of IL-1 $\beta$ CC in IBD patients, a genotype thought to be associated with low IL-1 $\beta$ levels. ${ }^{39}$ It is possible that the balance of high or low levels of IL$1 \beta$ is important in determining whether disease develops or in determining disease phenotype, rather than an overly pro-inflammatory genotype profile. It must also be noted that the association seen in this study was merely on the threshold of statistical significance $(p=0.046)$ and thus needs further investigation in order to determine a real association with the disease.

In the study population, there was a significant variation in TNF- $\alpha-308$ polymorphism genotype frequency when comparing the control group with the UC group. The control group contained a greater frequency of heterozygotes, and the UC group a greater frequency of homozygotes, especially GG, and thus the UC group had a lower frequency of carriers of the TNF- $\alpha-308$ A allele. Previously, Vatay et al. found the TNF- $\alpha-308$ A allele to be less frequent in both UC and $\mathrm{CD}$ patients compared with controls, ${ }^{43}$ and Bouma et al. found a lower frequency of the TNF- $\alpha-308$ A allele in UC patients compared with healthy controls. ${ }^{44}$ However, Louis et al. found a modest non-statistically significant reduction of -308 A allele frequency in $\mathrm{CD}$ patients compared with both UC patients and controls. ${ }^{45}$ Another study found no difference in TNF- $\alpha-308$ allele frequencies between controls and patients with fistulising CD, but did not look at frequency in UC patients. ${ }^{46}$ It therefore appears that there may be a slight association between the occurrence of UC and non-carriage of the $-308 \mathrm{~A}$ allele. This allele is generally associated with increased serum TNF- $\alpha$ levels, and the significance of its non-association with UC, an inflammatory condition, is yet to be elucidated, although it is possible that this polymorphism might play a role in the differences seen between subsets of patients with UC and CD.

When comparing the two IBD disease groups, it was observed that there was a higher number of IL6-174 and TNF- $\alpha-308$ heterozygotes in the CD group compared with the UC group for both polymorphisms. TNFB genotypes also differed between $\mathrm{UC}$ and CD groups, but did not reach statistical significance; this difference was possibly caused by linkage of the TNFB polymorphism to the TNF- $\alpha-308$ polymorphism. The explanation for why certain patient groups should contain a higher number of heterozygotes or homozygotes is unclear. Rather than being directly associated with the disease, these genotypes may serve merely as genetic markers for other genes. The associations between IBD and the TNF- $\alpha$ polymorphism have already been discussed. The IL-6-174 polymorphism was previously investigated in 169 CD patients, 133 UC patients and 440 healthy controls, and no significant difference in allele, genotype, or carrier frequencies between patients and controls was observed. ${ }^{47}$ The significance of the differences of the TNF- $\alpha$ and IL- 6 polymorphisms between the UC and $\mathrm{CD}$ groups seen in our study is not clear, but points to a potential difference in the pathophysiology of these two diseases, and the possibility that the effect of higher or lower levels of TNF- $\alpha$ and IL-6 may play different roles in patients with $\mathrm{UC}$ and $\mathrm{CD}$.

The IL-10-1082 polymorphism has been associated with susceptibility to IBD (UC or CD), and more significantly to UC alone; ${ }^{33}$ however, our study found no evidence to support these results, concurring with the results of Klein et al. who looked at both -1082 and -592 polymorphisms in $142 \mathrm{CD}$ patients, 104 UC patients and 400 controls, and found no differences in allele frequencies of either polymorphism between the groups studied. ${ }^{48}$ Allele 2 of the IL-1RN gene has been found at a greater frequency in a UC population compared with a control group. ${ }^{38}$ It is interesting to note that, although not statistically significant, the IL-1RN A2A2 genotype in our study was double the frequency in the $\mathrm{CD}$ group compared with both the UC and control groups, although this differs to the previous study where the association was for UC not CD. However, a previous study looked at the IL-1RN genotype in a large IBD population $(n=529)$ (divided into IBD subgroups) compared with controls $(n=289)$ and found no differences in genotype or allele frequencies, looking in particular at IL-1RN allele $2,{ }^{49}$ and it therefore appears likely that no real association between IBD and the IL-1RN VNTR exists. This lack of association has also been confirmed by a further study. ${ }^{50}$

In conclusion, this study provides evidence that polymorphisms in genes involved in the inflammatory response participate in determining susceptibility and disease phenotype in IBD patients, although not to a highly significant degree. Whether the polymorphisms are directly involved in regulating cytokine production, and consequently disease pathophysiology of IBD, or serve merely as markers that are in linkage disequilibrium with susceptibility genes is unclear. There does not appear to be any clear-cut correlation between alleles or genotypes that are associated with higher pro-inflammatory cytokine levels and disease occurrence. However, it may be that an imbalance in levels of the cytokines is 
an important factor in the development of IBD, rather than an overall pro-inflammatory profile.

\section{References}

1. Kumar P, Clark M. Clinical Medicine, 5th edn London, UK: WB Saunders; 2002

2. Greenberg GR, Feagan BG, Martin F, et al. Oral budesonide as maintenance treatment for Crohn's disease: a placebo-controlled, dose-ranging study. Canadian Inflammatory Bowel Disease Study Group. Gastroenterology 1996; 110: 45-51.

3. Munkholm P, Langholz E, Davidsen M, Binder V. Disease activity courses in a regional cohort of Crohn's disease patients. Scand J Gastroenterol 1995; 30: 699-706

4. Gross V, Andus T, Caesar I, Roth M, Scholmerich J. Evidence for continuous stimulation of interleukin- 6 production in Crohn's disease. Gastroenterology 1992; 102: 514-519.

5. Stevens C, Walz G, Singaram C, et al. Tumor necrosis factor-alpha, interleukin-1 beta, and interleukin- 6 expression in inflammatory bowel disease. Dig Dis Sci 1992; 37: 818-826.

6. Shanahan F. Crohn's disease. Lancet 2002; 359: 62-69.

7. van Dullemen HM, van Deventer SJ, Hommes DW, Bijl HA, Jansen J, Tytgat GN, Woody J. Treatment of Crohn's disease with anti-tumor necrosis factor chimeric monoclonal antibody (cA2). Gastroenterology 1995; 109: 129-135.

8. Targan SR, Hanauer SB, van Deventer SJ, et al. A short-term study of chimeric monoclonal antibody CA2 to tumor necrosis factor alpha for Crohn's disease. Crohn's Disease cA2 Study Group. N Engl J Med 1997; 337: 1029-1035.

9. Evans RC, Clarke L, Heath P, Stephens S, Morris AL, Rhodes JM. Treatment of ulcerative colitis with an engineered human anti-TNF alpha antibody CDP571. Aliment Pharmacol Therap 1997; 11: 1031 1035.

10. Cominelli F, Nast CC, Duchini A, Lee M. Recombinant interleukin-1 receptor antagonist blocks the proinflammatory activity of endogenous interleukin-1 in rabbit immune colitis. Gastroenterology 1992; 103: $65-$ 71.

11. Thomas TK, Will PC, Srivastava A, et al. Evaluation of an interleukin-1 receptor antagonist in the rat acetic acid-induced colitis model. Agent Actions 1991; 34: 187-190.

12. van Deventer SJ, Elson CO, Fedorak RN. Multiple doses of intravenous interleukin 10 in steroid-refractory Crohn's disease. Crohn's Disease Study Group. Gastroenterology 1997; 113: 383-389.

13. Schreiber S, Heinig T, Thiele HG, Raedler A. Immunoregulatory role of interleukin 10 in patients with inflammatory bowel disease. Gastroenterology 1995; 108: 1434-1444.

14. Tysk C, Lindberg E, Jarnerot G, Floderus-Myrhed B. Ulcerative colitis and Crohn's disease in an unselected population of monozygotic and dizygotic twins. A study of heritability and the influence of smoking. Gut 1988; 29: 990-996.

15. Roth MP, Petersen GM, McElree C, Vadheim CM, Panish JF, Rotter JI. Familial empiric risk estimates of inflammatory bowel disease in Ashkenazi Jews. Gastroenterology 1989; 96: 1016-1020

16. Fishman D, Faulds G, Jeffery R, Mohamed-Ali V, Yudkin JS, Humphries S, Woo P. The effect of novel polymorphisms in the interleukin-6 (IL-6) gene on IL- 6 transcription and plasma IL- 6 levels, and an association with systemic-onset juvenile chronic arthritis. J Clin Invest 1998; 102 $1369-1376$.

17. Nauck M, Winkelmann BR, Hoffman MM, Bohm BO, Wieland H, Marz W. The interleukin- $6 \mathrm{G}(-174) \mathrm{C}$ promoter polymorphism in the LURIC cohort: no association with plasma interleukin-6, coronary artery disease, and myocardial infarction. J Mol Med 2002; 80: 507-513.

18. Schluter B, Raufhake C, Erren M, et al. Effect of the interleukin-6 promoter polymorphism $(-174 \mathrm{G} / \mathrm{C})$ on the incidence and outcome of sepsis. Crit Care Med 2002; 30: 32-37.

19. Humphries SE, Luong LA, Ogg MS, Hawe E, Miller GJ. The interleukin$6-174 \mathrm{G} / \mathrm{C}$ promoter polymorphism is associated with risk of coronary heart disease and systolic blood pressure in healthy men. Eur J Heart 2001; 22: 2243-2252.

20. Messer G, Spengler U, Jung MC, et al. Polymorphic structure of the tumor necrosis factor (TNF) locus: an Ncol polymorphism in the first intron of the human TNF-beta gene correlates with a variant amino acid in position 26 and a reduced level of TNF-beta production. J Exp Med 1991; 173: 209-219.

21. Pociot F, Briant L, Jongeneel CV, et al. Association of tumor necrosis factor (TNF) and class II major histocompatibility complex alleles with the secretion of TNF-alpha and TNF-beta by human mononuclear cells a possible link to insulin-dependent diabetes mellitus. Eur J Immunol 1993; 23: 224-231

22. Stüber F, Petersen M, Bokelmann F, Schade U. A genomic polymorphism within the tumor necrosis factor locus influences plasma tumor necrosis factor-alpha concentrations and outcome of patients with severe sepsis. Crit Care Med 1996; 24: 381-384.
23. Whichelow CE, Hitman GA, Raafat I, Bottazzo GF, Sachs JA. The effect of TNF*B gene polymorphism on TNF-alpha and -beta secretion levels in patients with insulin-dependent diabetes mellitus and healthy controls. Eur J Immunogenet 1996; 23: 425-435.

24. Fang XM, Schroder S, Hoeft A, Stuber F. Comparison of two polymorphisms of the interleukin-1 gene family: interleukin-1 receptor antagonist polymorphism contributes to susceptibility to severe sepsis. Crit Care Med 1999; 27: 1330-1334.

25. Wilson AG, Symons JA, McDowell TL, McDevitt HO, Duff GW. Effects of a polymorphism in the human tumor necrosis factor alpha promoter on transcriptional activation. Proc Natl Acad Sci USA 1997; 94: 3195-3199.

26. Warzocha K, Ribeiro P, Bienvenu J, et al. Genetic polymorphisms in the tumor necrosis factor locus influence non-Hodgkin's lymphoma outcome. Blood 1998; 91: 3574-3581.

27. Fijen JW, Tulleken JE, Hepkema BG, van der Werf TS, Ligtenberg JJ, Zijlstra JG. The influence of tumor necrosis factor-alpha and interleukin10 gene promoter polymorphism on the inflammatory response in experimental human endotoxemia. Clin Infect Dis 2001; 33: $1601-$ 1603.

28. Nadel S, Newport MJ, Booy R, Levin M. Variation in the tumor necrosis factor-alpha gene promoter region may be associated with death from meningococcal disease. J Infect Dis 1996; 174: 878-880.

29. Mira JP, Cariou A, Grall F, et al. Association of TNF2, a TNF-alpha promoter polymorphism, with septic shock susceptibility and mortality: a multicenter study. JAMA 1999; 282: 561-568.

30. Turner DM, Williams DM, Sankaran D, Lazarus M, Sinnott PJ, Hutchinson IV. An investigation of polymorphism in the interleukin-10 gene promoter. Eur I Immunogenet 1997; 24: 1-8.

31. Lowe PR, Galley HF, Abdel-Fattah A, Webster NR. Influence of interleukin-10 polymorphisms on interleukin-10 expression and survival in critically ill patients. Crit Care Med 2003; 31: 34-38.

32. Koss K, Satsangi J, Fanning GC, Welsh KI, Jewell DP. Cytokine (TNF alpha, LT alpha and IL-10) polymorphisms in inflammatory bowel diseases and normal controls: differential effects on production and allele frequencies. Genes Immun 2000; 1: 185-190.

33. Tagore A, Gonsalkorale WM, Pravica V, et al. Interleukin-10 (IL-10) genotypes in inflammatory bowel disease. Tissue Antigens 1999; 54: 386-390.

34. Tarlow JK, Blakemore AI, Lennard A, Solari R, Hughes HN, Steinkasserer A, Duff GW. Polymorphism in human IL-1 receptor antagonist gene intron 2 is caused by variable numbers of an 86-bp tandem repeat. Hum Genet 1993; 91: 403-404

35. Danis VA, Millington M, Hyland VJ, Grennan D. Cytokine production by normal human monocytes: inter-subject variation and relationship to an IL-1 receptor antagonist (IL-1Ra) gene polymorphism. Clin Exp Immunol 1995; 99: 303-310.

36. Tountas NA, Casini-Raggi V, Yang H, et al. Functional and ethnic association of allele 2 of the interleukin-1 receptor antagonist gene in ulcerative colitis. Gastroenterology 1999; 117: 806-813.

37. Santtila S, Savinainen K, Hurme M. Presence of the IL-1RA allele 2 (IL1RN*2) is associated with enhanced IL-1beta production in vitro. Scand J Immunol 1998; 47: 195-198.

38. Mansfield JC, Holden H, Tarlow JK, et al. Novel genetic association between ulcerative colitis and the anti-inflammatory cytokine interleukin-1 receptor antagonist. Gastroenterology 1994; 106: 637-642.

39. Pociot F, Molvig J, Wogensen L, Worsaae H, Nerup J. A TaqI polymorphism in the human interleukin-1 beta (IL-1 beta) gene correlates with IL-1 beta secretion in vitro. Eur J Clin Invest 1992; 22: 396- 402 .

40. Dominici R, Malferrari G, Mariani C, Grimaldi L, Biunno I. The Interleukin 1-beta exonic $(+3953)$ polymorphism does not alter in vitro protein secretion. Exp Mol Pathol 2002; 73: 139-141.

41. Mark LL, Haffajee AD, Socransky SS, et al. Effect of the interleukin-1 genotype on monocyte IL-1beta expression in subjects with adult periodontitis. J Periodontal Res 2000; 35: 172-177.

42. Nemetz A, Nosti-Escanilla MP, Molnar T, et al. IL1B gene polymorphisms influence the course and severity of inflammatory bowel disease. Immunogenetics 1999; 49: 527-531.

43. Vatay A, Bene L, Kovacs A, et al. Relationship between the tumor necrosis factor alpha polymorphism and the serum C-reactive protein levels in inflammatory bowel disease. Immunogenetics 2003; 55: $247-$ 252.

44. Bouma G, Xia B, Crusius JB, et al. Distribution of four polymorphisms in the tumour necrosis factor (TNF) genes in patients with inflammatory bowel disease (IBD). Clin Exp Immunol 1996; 103: 391-396.

45. Louis E, Satsangi J, Roussomoustakaki M, Parkes M, Fanning G, Welsh K, Jewell D. Cytokine gene polymorphisms in inflammatory bowel disease. Gut 1996; 39: 705-710.

46. Gonzalez S, Martinez-Borra J, Torre-Alonso JC, et al. The MICA-A9 triplet repeat polymorphism in the transmembrane region confers additional susceptibility to the development of psoriatic arthritis and is independent of the association of $\mathrm{Cw}^{*} 0602$ in psoriasis. Arthritis Rheum 1999; 42: 1010-1016

47. Klein W, Tromm A, Griga T, et al. The polymorphism at position -174 of the IL-6 gene is not associated with inflammatory bowel disease. Eur J Gastroenterol Hepatol 2001; 13: 45-47. 
48. Klein W, Tromm A, Griga T, et al. The IL-10 gene is not involved in the predisposition to inflammatory bowel disease. Electrophoresis 2000; 21 $3578-3582$.

49. Craggs A, West $S$, Curtis A, Welfare $M$, Hudson $M$, Donaldson $P$, Mansfield J. Absence of a genetic association between IL-1RN and IL1B gene polymorphisms in ulcerative colitis and Crohns disease in multiple populations from northeast England. Scand I Gastroenterol 2001; 36: $1173-1178$
50. Hacker UT, Gomolka M, Keller E, et al. Lack of association between an interleukin-1 receptor antagonist gene polymorphism and ulcerative colitis Gut 1997; 40: 623-627.

\section{Received 6 April 2004}

Accepted 14 April 2004 


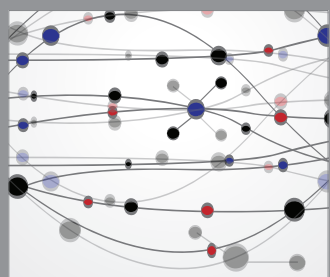

The Scientific World Journal
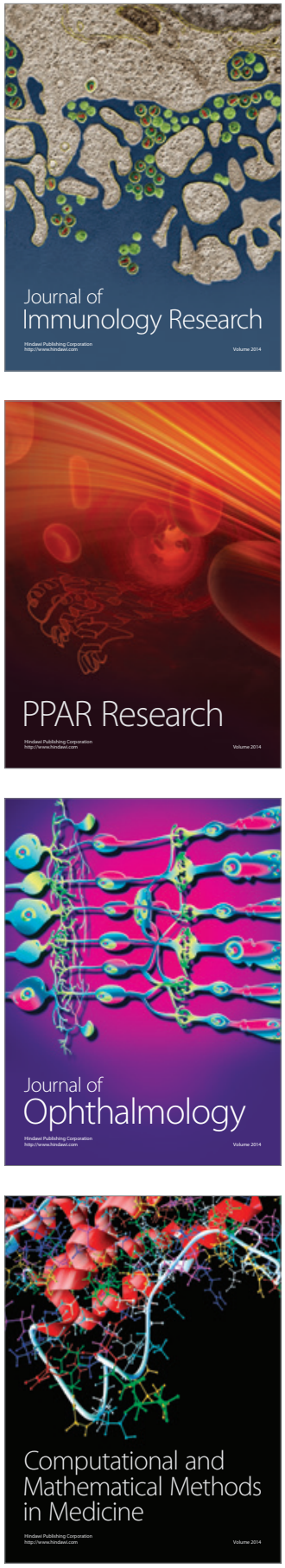

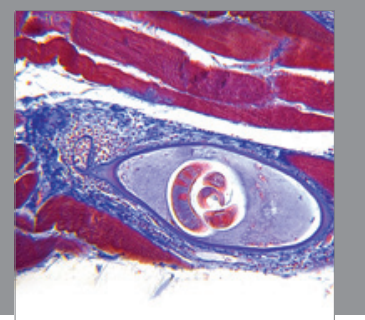

Gastroenterology

Research and Practice
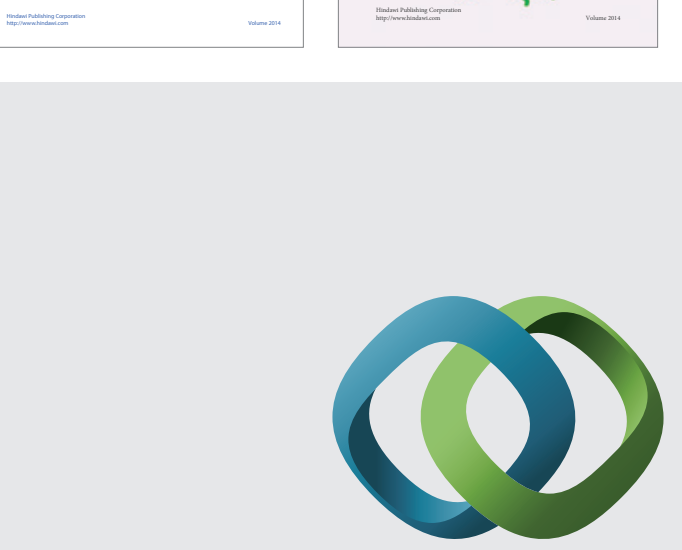

\section{Hindawi}

Submit your manuscripts at

http://www.hindawi.com
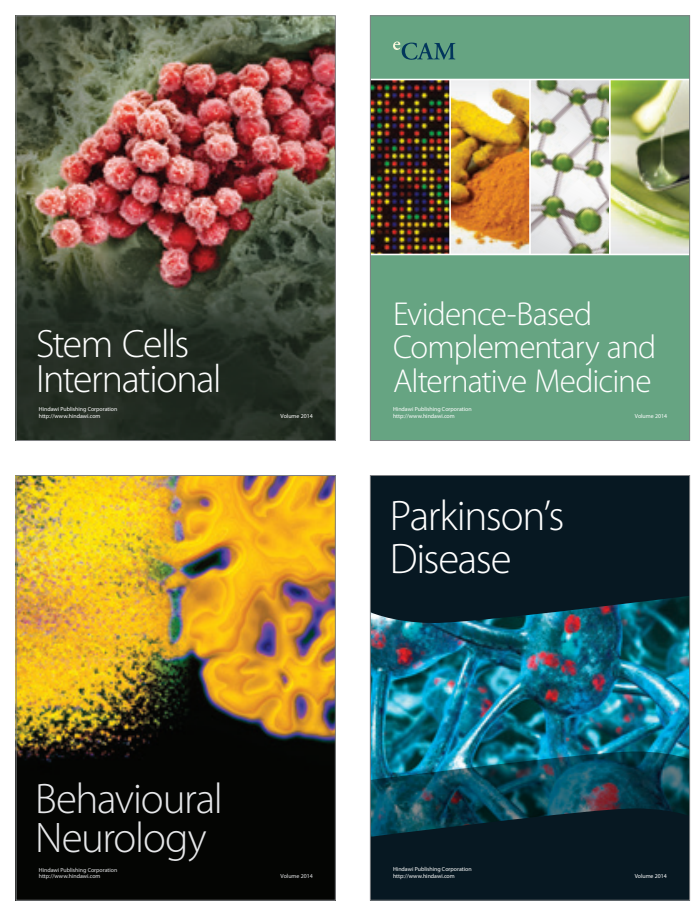

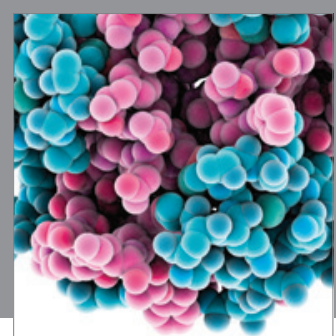

Journal of
Diabetes Research

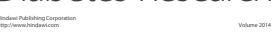

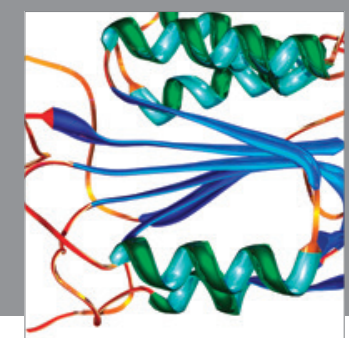

Disease Markers
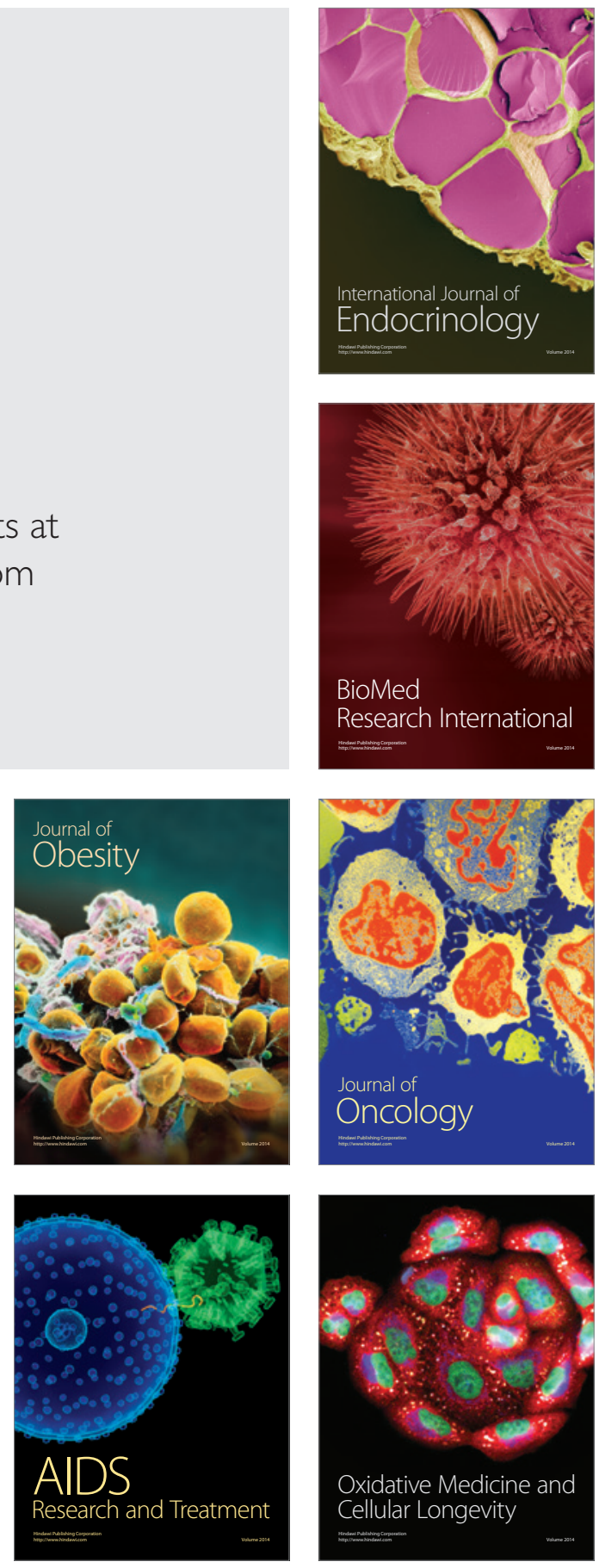